\title{
Epidemiology of Adenoid Cystic Carcinoma of the Breast in a Developing Community
}

\author{
Wilson IB Onuigbo* \\ Department of Pathology, Medical Foundation \& Clinic, 8 Nsukka Lane, Nigeria
}

Submission: October 25, 2016; Published: November 09, 2016

*Corresponding author: Wilson IB Onuigbo, Department of Pathology, Medical Foundation \& Clinic, 8 Nsukka Lane, Enugu, Nigeria, Email: wilson.onuigbo@gmail.com

\begin{abstract}
A well recognized rare breast entity is the adenoid cystic carcinoma [ACC]. Indeed, a few series have long been reported from several parts of the world. Now, according to the Birmingham [UK] group, there is the concept that the histopathology data pool promotes epidemiological analysis. Therefore, the purpose of this paper is to present from a developing community the data collected from such a pool with reference to women of the Ethnic Group called the Ibos or Igbos, who live mainly in the South-eastern region of Nigeria. Of the sixteen collected examples, most were gathered from the Cosmopolitan City of Enugu. Both sides were affected equally. The 31-50 age groups preponderated, while a particular surgeon dominated the operation scenery. Distant practitioners profit by sending biopsies to a centrally located Reference Laboratory.
\end{abstract}

Keywords: Breast; Type; Carcinoma; Adenoid cystic; Distance; Ibos; Enugu; Niger

\section{Introduction}

During the 1970s, there was a rise in the reprint request [RR] traffic. Thus, I freely received during that time single or few case reports as reprints on ACC at my request [1-5]. Incidentally, the microphotographs were compelling, although there were some variations. By 1980, Macartney, Rollaston and Codling [6] postulated from Birmingham (UK) that the establishment of a histopathology data pool would facilitate epidemiological analysis. Fortunately, this idea was in consonance with my own work in those days.

\section{Investigation}
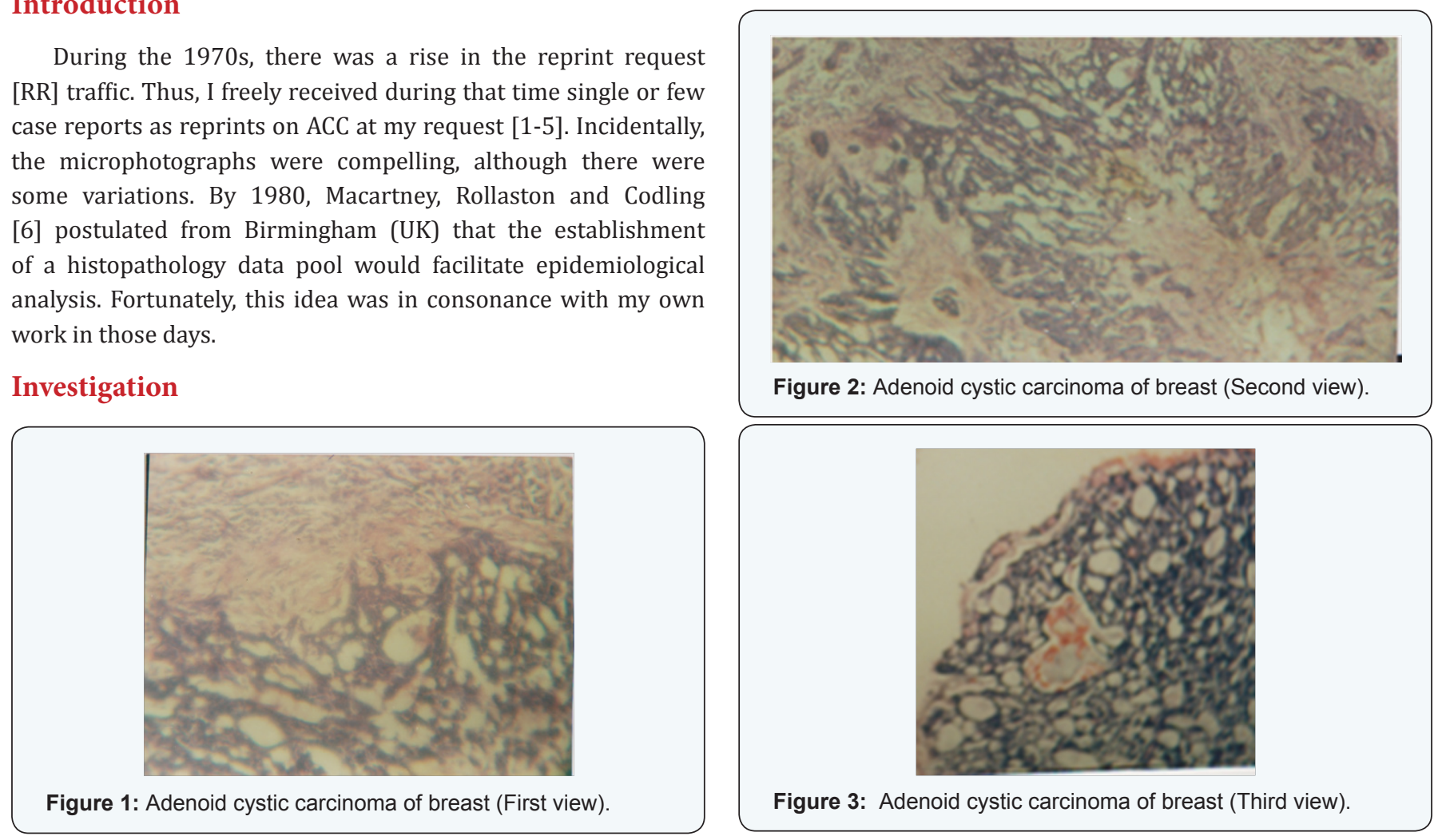
During the 1980s and 1990s, the author was privileged to head a Reference Pathology Laboratory situated in Enugu, the capital city of the then Eastern Region of Nigeria. Its histopathology data pool yielded 506 breast carcinomas, 16 being diagnosed personally as ACC. They are analyzed hereunder. Illustrative photographs are also adjoined (Figure 1-3).

\section{Results}

Table 1: Epidemiological data on adenoid cystic carcinoma of breast in a developing community.

\begin{tabular}{|c|c|c|c|c|c|c|}
\hline S/No. & Lab No & Initials & Age & Side & Town & Doctor \\
\hline 1 & $\begin{array}{c}\text { UH } \\
2157 / 85\end{array}$ & IR & 80 & $\mathrm{R}$ & Enugu & Ojukwu \\
\hline 2 & $\begin{array}{c}\text { UH } \\
2443 / 86\end{array}$ & IB & 51 & $\mathrm{R}$ & Enugu & Ojukwu \\
\hline 3 & $\begin{array}{c}\mathrm{UH} \\
802 / 89\end{array}$ & IJ & 45 & $\mathrm{R}$ & Enugu & Ojukwu \\
\hline 4 & $\begin{array}{c}\mathrm{UH} \\
1021 / 89\end{array}$ & $\mathrm{NJ}$ & 40 & $\mathrm{~L}$ & Owerri & $\begin{array}{c}\text { Iwenobi- } \\
\text { Njoku* }\end{array}$ \\
\hline 5 & 9709175 & $\mathrm{MM}$ & 40 & $\mathrm{R}$ & Abakaliki & Abiakam \\
\hline 6 & 9503178 & $\mathrm{MC}$ & 40 & $\mathrm{~L}$ & Umuahia & Mbanaso** \\
\hline 7 & 951061 & $\mathrm{EM}$ & 45 & $\mathrm{~L}$ & Enugu & Ojukwu \\
\hline 8 & 951084 & $\mathrm{KC}$ & 40 & $\mathrm{~L}$ & Enugu & Ojukwu \\
\hline 9 & 9603113 & $\mathrm{UN}$ & 35 & $\mathrm{R}$ & Enugu & Ojukwu \\
\hline 10 & 960463 & OF & 56 & $\mathrm{R}$ & Enugu & Ojukwu \\
\hline 11 & 96092 & NT & 46 & $\mathrm{~L}$ & Enugu & Njeze \\
\hline 12 & 961214 & OI & 47 & $\mathrm{~L}$ & Enugu & Ojukwu \\
\hline 13 & 970214 & OM & 58 & $\mathrm{R}$ & Ehime & Anyaeze \\
\hline 14 & 970335 & NR & 35 & $\mathrm{~L}$ & Enugu & Udeh \\
\hline 15 & $\mathrm{H} 51 / 98$ & $\mathrm{MR}$ & 30 & $\mathrm{~L}$ & Enugu & Achebe \\
\hline 16 & 990462 & $\mathrm{IC}$ & 39 & $\mathrm{R}$ & Enugu & Akahara \\
\hline
\end{tabular}

*Dr Iwenobi-Njoku wrote: "This is an uncommon form of breast cancers."

** $\mathrm{Dr}$ Mbanaso wrote: "The prognosis is reportedly better than the usual invasive ductal carcinoma."

Table 2: Age group distribution.

\begin{tabular}{|c|c|}
\hline Age & No \\
\hline$<30$ & 1 \\
\hline $31-40$ & 7 \\
\hline $41-50$ & 4 \\
\hline $51-60$ & 3 \\
\hline $61+$ & 1 \\
\hline Total & 16 \\
\hline
\end{tabular}

Tables 1 and 2 show the epidemiological analyses. It is evident

A. that the lesions featured equally on both sides,

B. most specimens were from the cosmopolitan city of Enugu,

C. there was preponderance in the 31-50 age groups and

D. Surgeon Ojukwu took pride of place.

\section{Discussion}

Among the RRs of the 1970s, let me select, on purpose, the careful work of Anthony and James [5]. They presented 3 cases from 2686 breast cancers within a period of 10 years. Moreover, as they agreed, "The term adenoid cystic carcinoma is the one recommended by the World Health Organization in preference to other synonyms." Their range of photographs confirmed the requisite appearances. Also noteworthy was its tendency to carry a uniquely favorable prognosis when compared with similar tumors elsewhere in the body.

In the local context, ACC was diagnosed in a 68-year-old surgeon well over a decade ago as regards his bowel cancer; it has till now proved truly prognostic [7]. Also, I have found it to be a molecular variant in local albino skin cancers [8]; their own follow up should also be fruitful.

Concerning the recent world literature, what are some pointers? From India, a 40-year-old female with final histopathologic diagnosis of ACC underwent adjuvant external beam radiotherapy and was on follow-up without recurrence for more than a year [9]. From Seoul, Korea [10], the report on 6 patients was to the effect that "Although some of our patients developed local recurrence or distant metastases, all patients had favorable clinical course, and to date, none of the patients has died from complications of her disease." Concerning a joint Korea-USA study [11], their comprehensive review provided experience with the ACC of the breast as well as an overview of clinical, histopathological, and molecular genetics, features. From the Mayo Clinic in USA [12], the conclusion was clear, namely, "Recognition of ACC is important to avoid delay in diagnosis because this tumor has a good prognosis with rare metastases to axillary lymph nodes. Axillary nodal sampling by fine-needle aspiration or core biopsy is rarely indicated."

A population-based cohort study of ACC in the United States (1977 to 2006) was conclusive [13]: Breast-ACC among women is characterized by ER-negative/PR-negative expression, rare regional lymph node involvement, a favorable prognosis with excellent survival, and absence of associated cancers. These findings reinforce the importance of tailored treatments for breast-ACC and lend credence to the apparent heterogeneity of basal-like breast cancers. Incidentally, there was debate in the UK as regards the benefit accruable to practitioners distant from a Reference Laboratory [14]. Indeed, the experience in this developing community is that of its desirability [15].

\section{References}

1. Verani RR, Bel-Kahn J (1973) Mammary adenoid cystic carcinoma with unusual features. AJCP 59(5): 653-658.

2. Lerner G, Molnar JJ, Adam YG (1974) Adenoid cystic carcinoma of the breast. Am J Surg 127(5): 585-587.

3. Qizilbash AH, Patterson MC, Oliveira KF (1977) Adenoid cystic carcinoma of the breast. Arch Pathol Lab Med 101(6): 302-306. 
4. Steinman A, Pepus M, McSwain G (1978) Adenoic cystic carcinoma of the breast. South Med J 71(7): 851-854.

5. Anthony PP, James PD (1975) Adenoid cystic carcinoma of the breast: prevalence, diagnostic criteria, and histogenesis. J Clin Pathol 28(8): 647-655.

6. Macartney JC, Rollaston TP, Codling BW (1980) Use of a histopathology data pool for epidemiological analysis. J Clin Pathol 33(4): 351-355.

7. Onuigbo WIB, Iweha U, Adisa AC (2016) Long survival with adenoid cystic carcinoma of the bowel in a Nigerian surgeon. Res Chron Hlth Sci 2(2): 269-271.

8. Onuigbo WIB (2016) Adenocystic carcinoma as a molecular variant of albino skin cancer. J Med Diagnost Method p.5:1.

9. Kumar BR, Padmanabhan N, Bose G, Paneer V (2015) A case report of adenoid cystic carcinoma of breast - so close yet so far from triple negative breast cancer. J Clin Diagn Res 9(7): XD01-XD03.

10. Kim M, Lee D, Im J, et al. (2014) Adenoid cystic carcinoma of the breast: A case series of six patients and literature review. Cancer Res Treat 46(1): 93-97.
11. Miyai K, Schwartz MR, Divatia MK, et al. (2014) Adenoid cystic carcinoma of breast: Recent advances. World J Clin Cases 2(12): 732741.

12. Glazebrook KN, Reynolds C, Smith RL, Gimenez EI, Boughey JC (2010) Adenoid cystic carcinoma of the breast. Am J Roentgenol 194(5): 1391-1396.

13. Ghabach B, Anderson WF, Curtis RE, Huycke MM, Lavigne JA, et al. (2010) Adenoid cystic carcinoma of the breast in the United States (1977 to 2006): a population-based cohort study. Breast Cancer Res 12(4): R54.

14. Lilleyman J (2002) From the president. Bull Roy Coll Pathol 117: 2-3.

15. Onuigbo WIB, Mbanaso AU (2005) Urban histopathology service for a remote Nigerian hospital. Bulletin of the Royal College of Pathologists 132: $32-34$.

Your next submission with JuniperPublishers will reach you the below assets

- Quality Editorial service

- Swift Peer Review

- Reprints availability

- E-prints Service

- Manuscript Podcast for convenient understanding

- Global attainment for your research

- Manuscript accessibility in different formats (Pdf, E-pub, Full Text, Audio)

- Unceasing customer service

Track the below URL for one-step submission http://juniperpublishers.com/online-submission.php 